\title{
Study and Analysis of the Effect of Chemical Composition of Spring Water of Dhofar Region Against Turbidity
}

\author{
Ahmmed Saadi Ibrahim*, Tafoul Abdullah Al Kathiri, Tariq Omar Hassan Al Rashidi and Salim Ahmed \\ Salim Al Shanfari \\ Department of Chemical Engineering, Dhofar University, Dhofar, 211, Sultanate of Oman \\ *Corresponding Author: ahmadsaadi47@yahoo.com
}

Submitted: $18 / 11 / 2019$

Revised: $\quad 31 / 05 / 2020$

Accepted: 16/08/2020

\begin{abstract}
The aim of this study is to calculate the physical properties of eight springs of the water of Dhofar region in Oman using physiochemical parameters like $\mathrm{pH}$, total dissolved solids (TDS), conductivity, turbidity, and dissolved oxygen (DO). The chemical properties estimated the concentrations of the metals in springs of water and specified the best healthy spring of water depending on the percentage difference between the actual and normal range set by the World Health Organization (WHO). Eight samples for each test were collected from eight springs of water, namely, Ain Hamran, Ain Deribat, Ain Tobruk, Ain Al-Nabi Ayoub, Ain Atom, Ain Jarziz, Ain Sahlnot, and Ain Razat using an atomic absorption spectrophotometer (AAS) to study the chemical composition of the samples. Ain Jarziz represented high quality water because the percentage difference between actual and WHO was 78.78\% compared to Ain Al-Nabi Ayoub, where the difference percentage was $105.95 \%$. Quantity of dissolved solid particles has a big effect on TDS and conductivity compared to the turbidity. Identification system was used to evaluate the effect of the quality of the chemical composition on the turbidity for Ions of $\mathrm{Cl}^{-1}, \mathrm{So}_{4}^{-2}, \mathrm{Ca}^{+2}, \mathrm{Na}^{+1}, \mathrm{Mg}^{+2}$, and $\mathrm{K}^{+1}$ to be equal to $99.52 \%, 75.4 \%$, $92.548 \%, 95.346 \%, 98.011 \%$, and $97.33 \%$, respectively. However, more studies are required to conform with the outcomes of this research employing this energetic technique.
\end{abstract}

Keywords: Springs water; Metals; Physical properties; Drinking water; Turbidity.

\section{INTRODUCTION}

Water stands second to the most important factors to keep the lifespan on the earth after air. Water requirements increase with the time due to the world consumption. Water in 2000 was close to 4000 billion cubic meters compared to approximately 4700 billion cubic meters in 2016. Requirement for the water increases with the rise of the populations (WHO, 2017). Springs of water symbolize a very important resource to supply water in Sultanate of Oman; especially, in Dhofar governorate, there are eight springs of water, namely, Ain Hamran, Ain Deribat, Ain Tobruk, Ain Al-Nabi Ayoub, Ain Atom, Ain Jazz, Ain Sahlnot, and Ain Razat. These springs are situated in the south of Sultanate of Oman.

The activity of humans in different fields of life increases the level of pollution of heavy metals that have been associated with increased risks of osteoporosis, high blood pressure, clogged arteries, nephrolithiasis (kidney stones), colorectal cancer, hypertension and stroke, coronary artery disease, insulin resistance, and obesity (WHO, 2017). Three 
to five million are killed due to waste of water, and more than one billion humans do not have appropriate drinking water (Nathan et al., 2019, Amani et al., 2019 \& Kawashima, 2003). Metals like iron, copper, Zink, magnesium, sodium, potassium, lithium, calcium, and boron create toxic effects on mankind, plants, and animals when their levels increase certain limits of safety (Muhammad et al., 2018, Nakahara, 2003; Ene et al., 2009, \& CaioVinicius et al., 2018).

Some researchers focus on the springs of water to study and analyze the pollution degree of these leaps of water (Saito, 2003, Nagoshi, 2005, Afzal et al., 2013, Pantelica et al., 2008, Ogoyi et al., 2011\& Gebrekidan M. \& Samuel Z., 2011). Spatial analysis of rare elements of thermal springs of water is performed, like Na-So4-Cl, Ca-So4-Cl, Arsenic (As), Na-Cl-HCO3, Mercury (Hg), etc. (Gautam P. \& Irfan A. , 2011, Popescu et al., 2009, Fujiwara S et al., 2007, Awni T, 2010, Ata S. et al., 2015, Mauricio O. et al., 2015, Eva et al., 2016, Falk et al., 2016, Gill G. \& Geesey et al., 2016, Sonia L. et al., 2019 \& M. Fernández et al., 2019 ).

Some researchers perform activities for desalination using advanced technology like polymeric membrane and nuclear desalination with a scope to convert wastewater into fresh water (Muhammad et al., 2018 \& Amani et al., 2019). The innovation of this work provides an active technique to merge actual, theoretical, and identification systems to evaluate the healthy level of spring water by comparing it against WHO standards as optimum value. Study and analysis of the effect of quality of chemical composition of springs of water against turbidity using an identification system due to this site has not been a debate, and the effect of quality chemical compositions against turbidity. This study will provide researchers with a reference for study and analysis of the interaction between quality of the chemical composition and turbidity, TDS, electrical conductivity, DO, and $\mathrm{pH}$.

\section{MATERIALS AND METHODS}

Eight water spring samples have been collected and gathered in $350 \mathrm{ml}$ precleaned polyethylene bottles, and we used density meter, viscometer, dissolved oxygen meter, total dissolved solids, electrical conductivity, and $\mathrm{pH}$ to recognize physical properties for each sample of spring of water. We used an atomic absorption photometer to measure the chemical composition of Magnesium $\left(\mathrm{Mg}^{+2}\right)$, Zinc $\left(\mathrm{Zn}^{+2}\right)$, Calcium $\left(\mathrm{Ca}^{+2}\right)$, Sodium $\left(\mathrm{Na}^{+1}\right)$, Potassium $\left(\mathrm{K}^{+1}\right)$, Cobalt (Co), Molybdenum (Mo), Cupper $\left(\mathrm{Cu}^{+2}\right)$, Iron $\left(\mathrm{Fe}^{+2}\right)$, manganese $(\mathrm{Mn})$, sulfate $\left(\mathrm{So}_{4}\right)$, and Fluoride (F-) for the eight samples of springs of water, depending on experimental results using identification system to estimate the percentage effect of each metal on turbidity as shown in Figure 1.

\section{RESULTS AND DISCUSSION}

\section{CHEMICAL TEST}

The allowable limit of elements of drinking water recommended by WHO for solutes is shown in Tables $1 \mathrm{a} \& 1 \mathrm{~b}$. The results showed that concentrations of Magnesium $\left(\mathrm{Mg}^{+2}\right)$, Calcium $\left(\mathrm{Ca}^{+2}\right)$, Sodium $\left(\mathrm{Na}^{+1}\right)$, Cobalt $(\mathrm{Co})$, Molbidium (Mo), and Iron $\left(\mathrm{Fe}^{+2}\right)$ were within the permissible limits set by WHO, while Zinc $\left(\mathrm{Zn}^{+2}\right)$, Potassium $\left(\mathrm{K}^{+1}\right)$, Sulfate $\left(\mathrm{So}_{4}^{-2}\right)$, Chloride $\left(\mathrm{Cl}^{-1}\right)$, Florid $\left(\mathrm{F}^{-1}\right)$, and Copper $\left(\mathrm{Cu}^{+2}\right)$ were less than the acceptable limits set by the WHO. Concentration of Manganese (Mn) was more than the acceptable limits set by the WHO as shown in Tables 1a and $1 \mathrm{~b}$. 


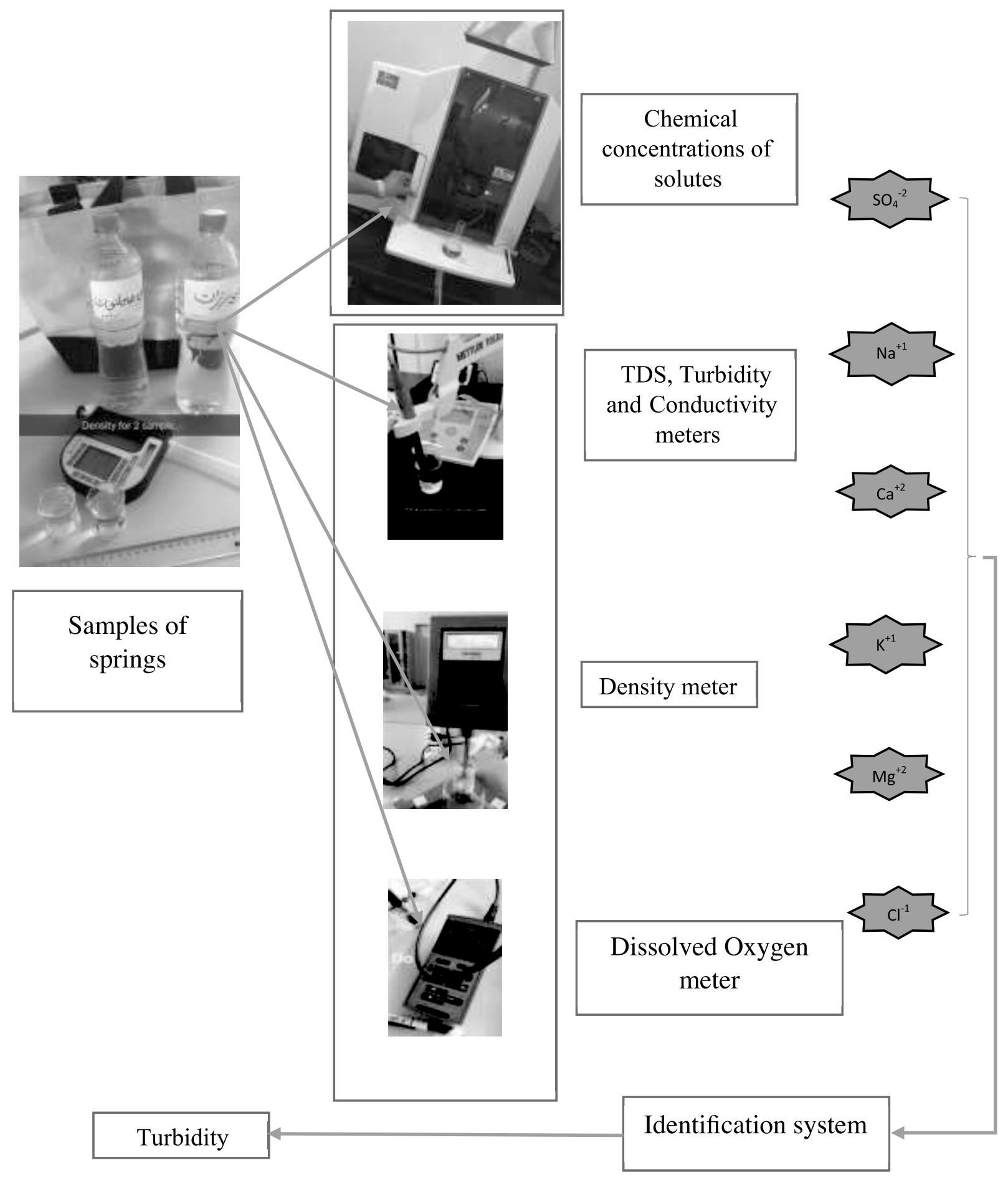

Figure 1. Physical and chemical equipment.

All springs of water are polluted by Mn, and springs of Himran, Derpat, Sahalnoot, and Razat are polluted by Mn and $\mathrm{Ca}$ as shown in Table 1a. The clear divergence in the distribution of concentrations is represented in standard deviation for $\mathrm{Ca}^{+2}, \mathrm{Na}^{+1}, \mathrm{Cl}^{-1}$ and $\mathrm{So}_{4}^{-2}$ as shown in Tables $1 \mathrm{a} \& \mathrm{~b}$, depending on the analysis of standard deviation to 
be more appropriate with the outcomes of identification system because the concentrations of $\mathrm{Cl}^{-1}, \mathrm{Ca}^{+2}$ and $\mathrm{Na}^{+1}$ have a high effect on the turbidity as shown in Tables 4, 6, \& 7, and concentration of So4-2 has a lower effect on turbidity as shown in Table 5.

Table 1a. Chemical concentration of different samples of spring water.

\begin{tabular}{|c|c|c|c|c|c|c|c|c|c|c|}
\hline $\begin{array}{l}\text { Springs of } \\
\text { water }\end{array}$ & $\begin{array}{c}\mathbf{M g}^{++} \\
(\mathrm{mg} / \mathrm{L})\end{array}$ & $\begin{array}{c}\mathrm{Zn}^{++} \\
(\mathrm{mg} / \mathrm{L})\end{array}$ & $\begin{array}{c}\mathrm{Ca}^{++} \\
(\mathrm{mg} / \mathrm{L})\end{array}$ & $\begin{array}{c}\mathrm{Na}^{+} \\
(\mathrm{mg} / \mathrm{L})\end{array}$ & $\begin{array}{c}\mathrm{K}^{+} \\
(\mathrm{mg} / \mathrm{L})\end{array}$ & $\begin{array}{c}\mathrm{Co} \\
(\mu \mathrm{g} / \mathrm{L})\end{array}$ & $\begin{array}{c}\text { Mo } \\
(\mu \mathrm{g} / \mathrm{L})\end{array}$ & $\begin{array}{c}\mathrm{Cu}^{+2} \\
(\mathrm{mg} / \mathrm{L})\end{array}$ & $\begin{array}{c}\mathrm{Fe}^{+2} \\
(\mathrm{mg} / \mathrm{L})\end{array}$ & $\begin{array}{c}\text { Mn } \\
(\mathrm{mg} / \mathrm{L})\end{array}$ \\
\hline $\begin{array}{c}\text { Springs of } \\
\text { water of } \\
\text { Himran }\end{array}$ & 11 & 0.328 & 93 & 14 & 1.83 & 0.235 & 0.190 & 0 & 0.002 & 0.094 \\
\hline $\begin{array}{c}\text { Springs of } \\
\text { water of } \\
\text { Deribat }\end{array}$ & 21 & 0.329 & 99 & 19 & 2.15 & 0.227 & 0.493 & 0 & 0.005 & 0.094 \\
\hline $\begin{array}{c}\text { Springs of } \\
\text { water of } \\
\text { Tobruk }\end{array}$ & 13 & 0.328 & 62 & 44 & 1.91 & 0.235 & 0.522 & 0 & 0.003 & 0.094 \\
\hline $\begin{array}{c}\text { Springs of } \\
\text { water of } \\
\text { Auyb }\end{array}$ & 20 & 0.328 & 86 & 8 & 4.85 & 0.244 & 0.582 & 0 & 0.003 & 0.096 \\
\hline $\begin{array}{c}\text { Springs of } \\
\text { water of } \\
\text { Athom }\end{array}$ & 25 & 0.337 & 38 & 59 & 1.49 & 0.247 & 0.695 & 0 & 0.003 & 0.099 \\
\hline $\begin{array}{c}\text { Sprins of } \\
\text { water of } \\
\text { Jarziz }\end{array}$ & 21 & 0.329 & 87 & 22 & 1.73 & 0.238 & 0.903 & 0 & 0.001 & 0.098 \\
\hline $\begin{array}{l}\text { Springs of } \\
\text { water of } \\
\text { Sahalnoot }\end{array}$ & 17 & 0.331 & 98 & 9 & 1.9 & 0.232 & 0.896 & 0 & 0.002 & 0.097 \\
\hline $\begin{array}{c}\text { Springs of } \\
\text { water of } \\
\text { Razat }\end{array}$ & 19 & 0.328 & 101 & 11 & 1.99 & 0.217 & 0.966 & 0 & 0.003 & 0.098 \\
\hline WHO & $2.1-53$ & 5 & $40-90$ & $\leq 200$ & 5.2 & $\leq 1$ & $\leq 10$ & 2 & $\leq 0.3$ & $\begin{array}{c}0.001- \\
0.05\end{array}$ \\
\hline $\begin{array}{l}\text { Standard } \\
\text { deviation }\end{array}$ & 4.56 & 0.003 & 22.026 & 18.514 & 1.075 & 0.009 & 0262. & 0 & 0.001 & 0.002 \\
\hline
\end{tabular}


Table 1b. Chemical concentration of different samples of spring water.

\begin{tabular}{|c|c|c|c|}
\hline Springs of water & $\begin{array}{c}\mathrm{F}^{-} \\
(\mathrm{mg} / \mathrm{L})\end{array}$ & $\begin{array}{c}\mathrm{Cl}^{-} \\
(\mathrm{mg} / \mathrm{L})\end{array}$ & $\begin{array}{c}\mathrm{So}_{4}{ }^{-2} \\
(\mathrm{mg} / \mathrm{L})\end{array}$ \\
\hline $\begin{array}{c}\text { Springs of water } \\
\text { of Himran }\end{array}$ & 0.01 & 86 & 9 \\
\hline $\begin{array}{c}\text { Springs of water } \\
\text { of Deribat }\end{array}$ & 0.27 & 94 & 22 \\
\hline $\begin{array}{c}\text { Springs of water } \\
\text { of Tobruk }\end{array}$ & 0.2 & 75 & 7 \\
\hline $\begin{array}{c}\text { Springs of water } \\
\text { of Auyb }\end{array}$ & 0.74 & 67 & 42 \\
\hline $\begin{array}{c}\text { Springs of water } \\
\text { of Athom }\end{array}$ & 0.17 & 66 & 14 \\
\hline $\begin{array}{l}\text { Sprins of water } \\
\text { of Jarziz }\end{array}$ & 0.87 & 85 & 30 \\
\hline $\begin{array}{c}\text { Springs of water } \\
\text { of Sahalnoot }\end{array}$ & 0.36 & 81 & 12 \\
\hline $\begin{array}{c}\text { Springs of water } \\
\text { of Razat }\end{array}$ & 0.6 & 84 & 9 \\
\hline WHO & $0.6-1.4$ & $200-600$ & $250-500$ \\
\hline $\begin{array}{l}\text { Standard } \\
\text { deviation }\end{array}$ & 0.302 & 9.735 & 12.418 \\
\hline
\end{tabular}

\section{PHYSICAL TEST}

The acceptance ranges of physical properties of drinking water were specified by WHO for $\mathrm{pH}$, TDS, conductivity, turbidity, and DO as shown in Table 2. In all samples, the properties of physical test were through an acceptable range except the value of conductivity that was more than the acceptable range and springs of Ain Hamran that were through acceptable range as shown in Table 2. Table 2 presents the results of evaluation parameters of spring water showing that TDS and electrical conductivity had higher values in the spring of Deribat compared to the turbidity value that had a lower value compared to the other springs of water. Also, TDS and electrical conductivity had lower values in spring of Himran compared to the turbidity value that had a higher value compared to the other springs of water. So, from the outcomes above, it appears that TDS is proportional with the electrical conductivity compared to the turbidity depending on the quality of chemical composition of solutes as shown in Table 2. 
Table 2. Physiochemical parameters of water samples.

\begin{tabular}{|c|c|c|c|c|c|c|}
\hline $\begin{array}{l}\text { Springs of } \\
\text { water }\end{array}$ & $\begin{array}{c}\text { Density } \\
\left(\mathrm{gm} / \mathrm{cm}^{3}\right)\end{array}$ & $\begin{array}{c}\text { TDS } \\
(\mathrm{mg} / \mathrm{L})\end{array}$ & $\begin{array}{c}\text { DO } \\
(\mathrm{mg} / \mathrm{L})\end{array}$ & $\begin{array}{l}\text { Turbidity } \\
\text { NTU }\end{array}$ & $\begin{array}{c}\text { Conductivity } \\
\mu \mathrm{S} / \mathrm{cm}\end{array}$ & pH \\
\hline $\begin{array}{c}\text { Ain } \\
\text { Humran }\end{array}$ & 0.999 & 391 & 8.09 & 1.94 & 791 & 8.08 \\
\hline Ain Deribat & 0.944 & 523 & 7.086 & 0.16 & 1047 & 7.67 \\
\hline Ain Tobruk & 1.0000 & 429 & 6.903 & 0.33 & 848 & 7.82 \\
\hline $\begin{array}{l}\text { Ain Alnabi } \\
\text { Ayoub }\end{array}$ & 0.999 & 481 & 7.216 & 1.14 & 953 & 8.17 \\
\hline Ain Athom & 0.9997 & 407 & 6.856 & 0.45 & 808 & 7.8 \\
\hline Ain Jrziz & 0.999 & 463 & 7.68 & 1.13 & 931 & 7.69 \\
\hline Ain Sahlnot & 0.999 & 427 & 7.736 & 0.34 & 879 & 7.42 \\
\hline Ain Razat & 1.000 & 491 & 7.56 & 0.18 & 1015 & 7.49 \\
\hline WHO & 1.000 & $300-800$ & $7-10$ & $\leq 5$ & $200-800$ & $6.5-8.5$ \\
\hline $\begin{array}{l}\text { Standard } \\
\text { deviation }\end{array}$ & 0.0196 & 45.39 & 0.442 & 0.633 & 93.691 & 0.261 \\
\hline
\end{tabular}

\section{OPTIMIZATION STUDY}

Depending on World Health Organization (WHO) that represents the optimum chemical composition for healthy water to represent the objective function and trying to calculate the difference percentage between actual and optimum of WHO results as shown in Table 3 and Figure 2, springs of water of Ain Jarziz, Ain Deribat, Ain Razat, Ain Sahlnot, Ain Humran, Ain Tobruk, Ain Athom, and Ain Alnabi Ayoub represent first, second, third, fourth, fifth, sixth, seventh, and eighth optimum healthy springs of water, respectively. 
Table 3. Average percentage difference between experimental results and optimum value of WHO.

\begin{tabular}{|c|c|c|c|c|c|c|c|c|c|}
\hline \multirow[b]{2}{*}{$\begin{array}{c}\text { Concentration } \\
\text { of metals } \\
\end{array}$} & \multicolumn{8}{|c|}{ Springs of water } & \multirow[b]{2}{*}{ WHO } \\
\hline & $\begin{array}{c}\text { Ain } \\
\text { Humran }\end{array}$ & $\begin{array}{c}\text { Ain } \\
\text { Deribat }\end{array}$ & $\begin{array}{c}\text { Ain } \\
\text { Tobruk }\end{array}$ & $\begin{array}{c}\text { Ain Alnabi } \\
\text { Ayoub }\end{array}$ & $\begin{array}{c}\text { Ain } \\
\text { Athom }\end{array}$ & $\begin{array}{c}\text { Ain } \\
\text { Jarziz }\end{array}$ & $\begin{array}{c}\text { Ain } \\
\text { Sahlnot }\end{array}$ & $\begin{array}{c}\text { Ain } \\
\text { Razat }\end{array}$ & \\
\hline $\mathrm{Mg}^{+2}(\mathrm{mg} / \mathrm{L})$ & 0.5677 & 0.1748 & 0.4891 & 0.2141 & 0.0176 & 0.1748 & 0.332 & 0.2534 & 25.45 \\
\hline $\mathrm{Zn}^{+2}(\mathrm{mg} / \mathrm{L})$ & 0.9344 & 0.9342 & 0.9344 & 0.9344 & 0.9326 & 0.9342 & 0.9338 & 0.9344 & 5 \\
\hline $\mathrm{Ca}^{+2}(\mathrm{mg} / \mathrm{L})$ & 0.55 & 0.571 & 0.033 & 0.4333 & 0.3666 & 0.45 & 0.6346 & 0.6833 & 5 \\
\hline $\mathrm{Na}^{+1}(\mathrm{mg} / \mathrm{L})$ & 0.3 & 0.05 & 1.2 & 3.3 & 1.95 & 0.1 & 0.55 & 0.45 & 20 \\
\hline $\mathrm{K}^{+1}(\mathrm{mg} / \mathrm{L})$ & 0.648 & 0.5865 & 0.6326 & 0.6 & 0.7134 & 0.6673 & 0.6346 & 0.6173 & 5.2 \\
\hline $\operatorname{Co}(\mu \mathrm{g} / \mathrm{L})$ & 0.235 & 0.227 & 0.235 & 0.244 & 0.247 & 0.238 & 0.232 & 0.217 & 1 \\
\hline $\operatorname{Mo}(\mu \mathrm{g} / \mathrm{L})$ & 0.019 & 0.0493 & 0.0522 & 0.0582 & 0.0695 & 0.0903 & 0.0896 & 0.0966 & 10 \\
\hline $\mathrm{Fe}^{+2}(\mathrm{mg} / \mathrm{L})$ & 0.0066 & 0.0166 & 0.01 & 0.01 & 0.01 & 0.0033 & 0.0066 & 0.01 & 0.3 \\
\hline $\mathrm{Mn}(\mathrm{mg} / \mathrm{L})$ & 5.266 & 5.266 & 5.266 & 5.4 & 5.6 & 5.53 & 5.46 & 5.53 & 0.015 \\
\hline $\mathrm{F}^{1}(\mathrm{mg} / \mathrm{L})$ & 0.99 & 0.73 & 0.8 & 0.26 & 0.83 & 0.13 & 0.64 & 0.4 & 1 \\
\hline $\mathrm{Cl}^{1}(\mathrm{mg} / \mathrm{L})$ & 0.785 & 0.765 & 0.8125 & 0.8325 & 0.835 & 0.7875 & 0.7975 & 0.79 & 400 \\
\hline $\mathrm{So}_{4}^{2}(\mathrm{mg} / \mathrm{L})$ & 0.3866 & 0.2373 & 0.376 & 0.4266 & 0.2906 & 0.3493 & 0.328 & 0.3226 & 375 \\
\hline $\begin{array}{l}\text { Average\% difference } \\
=\frac{(\text { Actual }-W H O)}{W H O} 100\end{array}$ & 0.88 & 0.8006 & 0.9034 & 1.0594 & 0.988 & 0.7878 & 0.886 & 0.858 & 0 \\
\hline
\end{tabular}

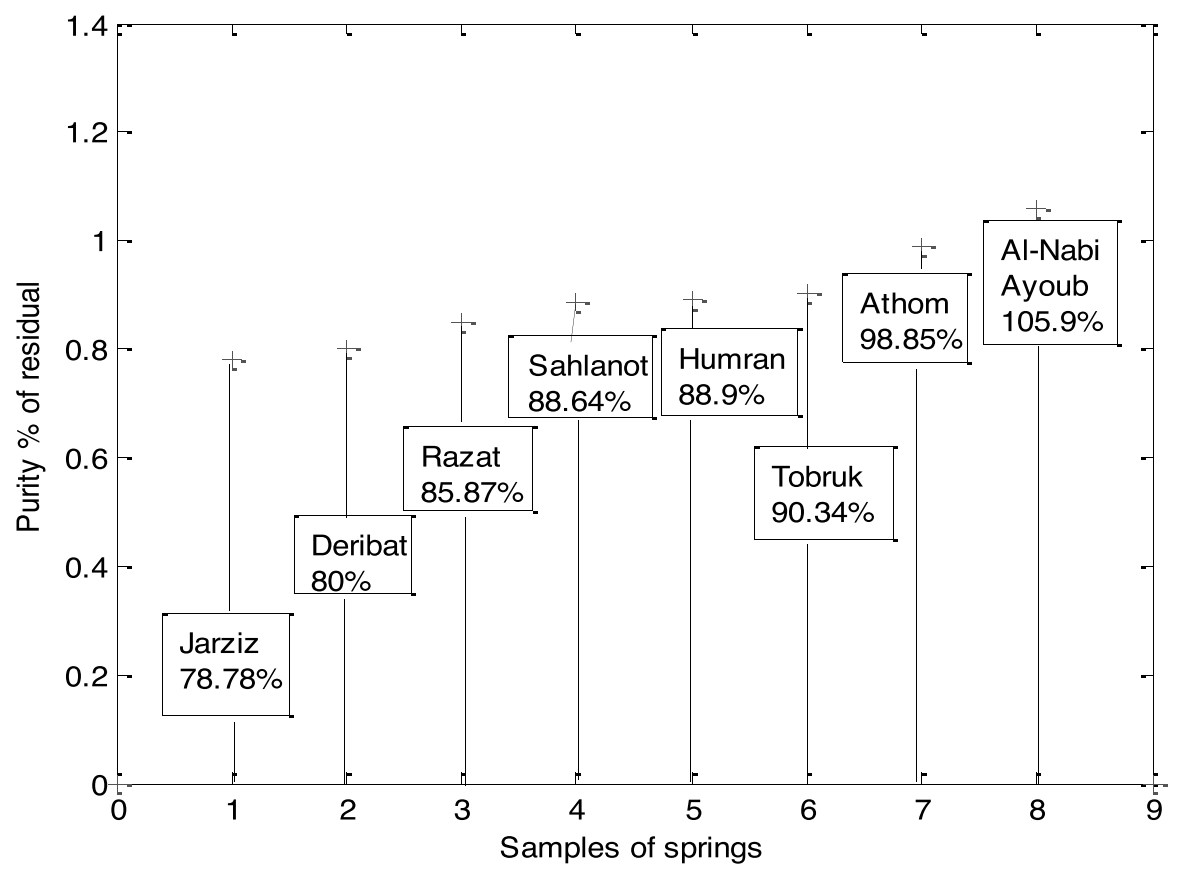

Figure 2. Comparison between purity $\%$ of springs of water and WHO to specify the optimization springs of water. 


\section{IDENTIFICATION SYSTEM FOR ACTUAL DATA}

Depending on the outcomes of physical and chemical properties of spring water the quantity of total dissolved solids of organic and inorganic compounds has big effects on TDS, DO, and conductivity compared to turbidity. Turbidity depends on the quality of chemical composition of water. So, an identification system was employed to specify the effects of these six input elements on the turbidity as output for $\mathrm{Cl}^{-1}, \mathrm{So}_{4}^{-2}, \mathrm{Ca}^{+2}, \mathrm{Na}^{+1}, \mathrm{Mg}^{+2}$, and $\mathrm{K}^{+1}$ to be equal to 99.52\%, 75.4\%, 92.548\%, 95.346\%, 98.011\%, and 97.33\%, respectively, as shown in Figure 3 (Ahmmed et al., 2009). Tables 4 to 9 represent the details of identification system for $\mathrm{Cl}^{-1}, \mathrm{So}^{-2}, \mathrm{Ca}^{+2}, \mathrm{Na}^{+1}, \mathrm{Mg}^{+2}$, and $\mathrm{K}^{+1}$, respectively. The final results of identification system are in good agreement with the results of higher value of turbidity due to the high concentrations of $\mathrm{Cl}^{-2}$ and $\mathrm{Ca}^{+2}$ of spring of Himran, which are $86(\mathrm{mg} / \mathrm{L})$ and $93(\mathrm{mg} / \mathrm{L})$, respectively. Ions of $\mathrm{Cl}^{-1}$ and $\mathrm{Ca}^{+2}$ have a big effect on turbidity, about $99.52 \%$ and $92.548 \%$, respectively, to increase the turbidity. Turbidity value was lower for the spring of Deribat because the high concentration of $\mathrm{So}_{4}{ }^{-2}$, about $22(\mathrm{mg} / \mathrm{L})$, has lower effects on the turbidity of about $75.4 \%$.

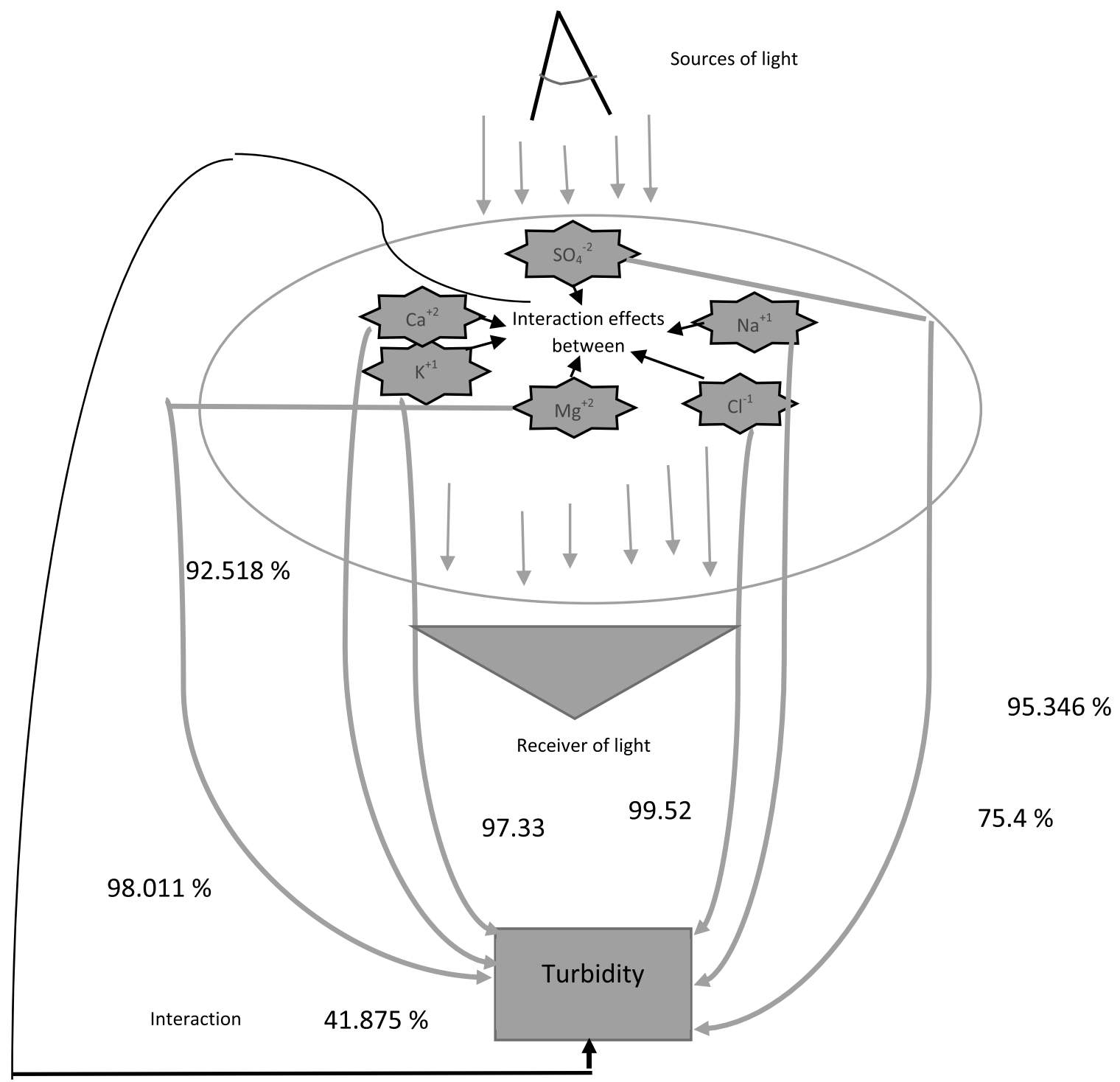

Figure 3. Identification system of water springs. 
Table 4. Identification system of $\mathrm{Cl}^{-1}$ effects.

\begin{tabular}{|c|c|c|c|c|}
\hline $\mathbf{X}_{\mathbf{i}},\left(\mathbf{C l}^{-\mathbf{1}}\right) \mathbf{~ \mathbf { ~ g } / \mathbf { l }}$ & $\left.\mid \mathbf{X}_{\mathbf{i}}-\mathbf{X}_{\mathbf{n}}\right) / \mathbf{X}_{\mathbf{n}} \mid$ & $\mathbf{Y}_{\mathbf{i}}$ (Turbidity) & $\left|\left(\mathbf{Y}_{\mathbf{i}}-\mathbf{Y}_{\mathbf{n}}\right) / \mathbf{Y}_{\mathbf{n}}\right|$ & Slope \\
\hline 66 & 0.214 & 0.45 & 1.5 & 7.01 \\
\hline 67 & 0.202 & 1.14 & 5.333 & 26.401 \\
\hline 75 & 0.107 & 0.33 & 0.833 & 7.785 \\
\hline 81 & 0.035 & 0.314 & 0.888 & 25.371 \\
\hline 84 & 0 & 0.18 & 0 & 0 \\
\hline 85 & 0.012 & 1.13 & 5.277 & 439.75 \\
\hline 86 & 0.023 & 1.94 & 9.777 & 425.087 \\
\hline 94 & 0.12 & 0.16 & 0.111 & 0.925 \\
\hline
\end{tabular}

$\theta=\tan ^{-1}$ Average slope $=\tan ^{-1} 133.19=\theta=89.52^{\circ}$

$$
\% \text { effect }=\frac{\theta}{90^{\circ}}=\frac{89.52}{90} \times 100=99.52 \%
$$

Table 5. Identification system of $\mathrm{SO}_{4}^{-2}$ effects.

\begin{tabular}{|c|c|c|c|c|}
\hline $\mathbf{X}_{\mathbf{i}},\left(\mathbf{S O}_{\mathbf{4}}\right) \mathbf{m g} / \mathbf{l}$ & $\left|\left(\mathbf{X}_{\mathrm{i}}-\mathbf{X}_{\mathbf{n}}\right) / \mathbf{X}_{\mathbf{n}}\right|$ & $\mathbf{Y}_{\mathbf{i}}$ (Turbidity) & $\left|\left(\mathbf{Y}_{\mathrm{i}}-\mathbf{Y}_{\mathbf{n}}\right) / \mathbf{Y}_{\mathbf{n}}\right|$ & Slope \\
\hline 7 & 0.5 & 0.33 & 0.266 & 0.532 \\
\hline 9 & 0.357 & 1.94 & 3.311 & 9.274 \\
\hline 12 & 0.142 & 0.34 & 0.244 & 1.718 \\
\hline 14 & 0 & 0.45 & 0 & 0 \\
\hline 22 & 0.571 & 0.16 & 0.644 & 1.127 \\
\hline 30 & 1.142 & 1.13 & 1.511 & 1.323 \\
\hline 42 & 2 & 1.14 & 1.533 & 0.766 \\
\hline & & & & $\begin{array}{c}\text { Average } \\
\text { slope=2.405 }\end{array}$ \\
\hline
\end{tabular}

$\theta=\tan ^{-1}$ Average slope $=\tan ^{-1} 2.405=\theta=67.85^{\circ}$

$$
\% \text { effect }=\frac{\theta}{90^{\circ}}=\frac{67.85}{90} \times 100=75.4 \%
$$


Table 6. Identification system of $\mathrm{Ca}+^{2}$ effects.

\begin{tabular}{|c|c|c|c|c|}
\hline $\mathbf{X}_{\mathbf{i}},\left(\mathbf{C} \mathbf{a}{ }^{2}\right) \mathbf{~ m g} / \mathbf{l}$ & $\left|\left(\mathbf{X}_{\mathbf{i}}-\mathbf{X}_{\mathbf{n}}\right) / \mathbf{X}_{\mathbf{n}}\right|$ & $\mathbf{Y}_{\mathbf{i}}$ (Turbidity) & $\left|\left(\mathbf{Y}_{\mathbf{i}}-\mathbf{Y}_{\mathbf{n}}\right) / \mathbf{Y}_{\mathbf{n}}\right|$ & Slope \\
\hline 38 & 0.59 & 0.48 & 0.75 & 1.271 \\
\hline 62 & 0.33 & 0.33 & 0.83 & 2.515 \\
\hline 86 & 0.07 & 1.14 & 0.41 & 2.857 \\
\hline 87 & 0.06 & 1.13 & 0.41 & 6.833 \\
\hline 93 & 0 & 1.94 & 0 & 0 \\
\hline 98 & 0.05 & 0.34 & 0.82 & 16.4 \\
\hline 99 & 0.06 & 0.16 & 0.91 & 15.166 \\
\hline 101 & 0.08 & 0.18 & 0.9 & 11.25 \\
\hline
\end{tabular}

$\theta=\tan ^{-1}$ Average slope $=\tan ^{-1} 8.47=\theta=83.26^{\circ}$

$$
\% \text { effect }=\frac{\theta}{90^{\circ}}=\frac{83.26}{90} \times 100=92.518 \%
$$

Table 7. Identification system of $\mathrm{Na}^{+1}$ effects.

\begin{tabular}{|c|c|c|c|c|}
\hline $\mathbf{X}_{\mathbf{i}} \mathbf{( \mathbf { N a }} \mathbf{N}^{+\mathbf{1}} \mathbf{\mathbf { m g }} / \mathbf{l}$ & $\left.\mid \mathbf{X}_{\mathbf{i}}-\mathbf{X}_{\mathbf{n}}\right) / \mathbf{X}_{\mathbf{n}} \mid$ & $\mathbf{Y}_{\mathbf{i}}$ (Turbidity) & $\left|\left(\mathbf{Y}_{\mathbf{i}}-\mathbf{Y}_{\mathbf{n}}\right) / \mathbf{Y}_{\mathbf{n}}\right|$ & Slope \\
\hline 8 & 0.579 & 1.14 & 6.125 & 10.578 \\
\hline 9 & 0.526 & 0.34 & 1.126 & 2.138 \\
\hline 11 & 0.421 & 0.18 & 0.125 & 0.296 \\
\hline 14 & 0.263 & 1.94 & 11.125 & 42.3 \\
\hline 19 & 0 & 0.16 & 0 & 0 \\
\hline 22 & 0.157 & 1.13 & 6.062 & 38.611 \\
\hline 44 & 1.315 & 0.33 & 1.062 & 0.807 \\
\hline 59 & 2.105 & 0.45 & 1.812 & 0.86 \\
\hline
\end{tabular}

$\theta=\tan ^{-1}$ Average slope $=\tan ^{-1} 13.656=\theta=85.812^{\circ}$

$$
\% \text { effect }=\frac{\theta}{90^{\circ}}=\frac{85.812}{90} \times 100=95.346 \%
$$


Table 8. Identification system of $\mathrm{Mg}^{+2}$ effects.

\begin{tabular}{|c|c|c|c|c|}
\hline $\mathrm{X}_{\mathrm{i}},\left(\mathrm{Mg}^{+2}\right) \mathrm{mg} / \mathrm{l}$ & $\left|\left(\mathbf{X}_{\mathrm{i}}-\mathbf{X}_{\mathbf{n}}\right) / \mathbf{X}_{\mathbf{n}}\right|$ & $\mathbf{Y}_{\mathbf{i}}$ (Turbidity) & $\left|\left(\mathbf{Y}_{\mathrm{i}}-\mathbf{Y}_{\mathbf{n}}\right) / \mathbf{Y}_{\mathrm{n}}\right|$ & Slope \\
\hline 11 & 0.421 & 1.94 & 9.777 & 23.223 \\
\hline 13 & 0.315 & 0.33 & 0.833 & 2.644 \\
\hline 17 & 0.105 & 0.34 & 0.888 & 8.457 \\
\hline 19 & 0 & 0.18 & 0 & 0 \\
\hline 20 & 0.052 & 1.14 & 5.333 & 102.557 \\
\hline 21 & 0.105 & 1.13 & 5.277 & 50.257 \\
\hline 25 & 0.315 & 0.45 & 1.5 & 4.762 \\
\hline & & & & $\begin{array}{l}\text { Average } \\
\text { slope }=32\end{array}$ \\
\hline
\end{tabular}

$\theta=\tan ^{-1}$ Average slope $=\tan ^{-1} 32=\theta=88.21^{\circ}$

$$
\% \text { effect }=\frac{\theta}{90^{\circ}}=\frac{88.12}{90} \times 100=98.011 \%
$$

Table 9. Identification system of $\mathrm{K}^{+1}$ effects.

\begin{tabular}{|c|c|c|c|c|}
\hline $\mathbf{X}_{\mathbf{i}},\left(\mathbf{K}^{+\mathbf{1}}\right) \mathbf{~ m g} / \mathbf{l}$ & $\left.\mid \mathbf{X}_{\mathbf{i}}-\mathbf{X}_{\mathbf{n}}\right) / \mathbf{X}_{\mathbf{n}} \mid$ & $\mathbf{Y}_{\mathbf{i}}$ (Turbidity) & $\left|\left(\mathbf{Y}_{\mathbf{i}}-\mathbf{Y}_{\mathbf{n}}\right) / \mathbf{Y}_{\mathbf{n}}\right|$ & Slope \\
\hline 1.49 & 0.22 & 0.45 & 0.363 & 1.65 \\
\hline 1.73 & 0.09 & 1.14 & 2.424 & 26.93 \\
\hline 1.83 & 0.041 & 1.94 & 4.878 & 110 \\
\hline 1.9 & 0.011 & 0.34 & 0.03 & 2.727 \\
\hline 1.91 & 0 & 0.33 & 0 & 0 \\
\hline 1.99 & 0.041 & 0.18 & 0.454 & 11.073 \\
\hline 2.15 & 0.125 & 0.16 & 0.515 & 4.12 \\
\hline 4.85 & 1.54 & 1.14 & 2.454 & 1.59 \\
\hline & & & & $\begin{array}{c}\text { Average } \\
\text { slope=23.864 }\end{array}$ \\
\hline
\end{tabular}

$$
\theta=\tan ^{-1} \text { Average slope }=\tan ^{-1} 23.864=\theta=87.6^{\circ}
$$

$$
\% \text { effect }=\frac{\theta}{90^{\circ}}=\frac{87.6}{90} \times 100=97.33 \%
$$




\section{CONCLUSION}

1. The comparison between actual and WHO outcomes of physical and chemical properties leads to specifying the best healthy spring water as Ain Jarziz compared to Ain Al-Nabi Ayoub that represents the lowest healthy spring water.

2. Quality of chemical composition of organic and inorganic has big effects on turbidity.

3. Quantity of the chemical composition has active effects on TDS, DO, and electrical conductivity compared to turbidity.

4. The outcomes of this study using an identification system help researchers recognize and evaluate the relation between the quality of the chemical composition towards turbidity, TDS, DO, and electrical conductivity and create the mathematical relation between these parameters.

\section{REFERENCES}

Afzal, S., Abdul, N., Nazeef, U., Ali, R., Muhammad, A., Muhammad, Z. \& Muhammad, S.K. 2013. Comparative Study of Heavy Metals in Soil and Selected Medicinal Plants. J.of Chemistry. 5: 203-214.

Ahmmed, S.I., Mohamed, A.H., Nayef, M.G. 2009. Dynamic Analysis And System Identification Of Polyethylene Process. J. of Chemical and Natural Resources Engineering. 3: 33-44.

Amani, A., Noora, N., Muhammad, Q., Mohammad, T., Naif, A. \& Nidal, H. 2019. Desalination: A State-of-the-Art Review, Desalination. 457: 39-61.

Ata, S., Sayedkazem G., Behzad M. \& Morteza D. 2015. Rare earth elements geochemistry in springs from Taftan geothermal area SE Iran. J. of Volcanology and Geothermal Research. 304: 49-61.

Awni, T., Batayneh. 2010. Heavy metals in water springs of the Yarmouk Basin,North Jordan and their potentiality in health risk assessment. J. International Journal of the Physical Sciences. 5(7): 997-1003.

Caio, V., Ferreira, M.M., Esteban, L., Borjab, V., Antonio, R. D. \& Antonio, Z. 2018. Effects of land use and sampling distance on water quality in tropical headwater springs. J.Science of The Total Environment. 622: 690-701.

Ene, I.V. \& Popescu, C., Stihi. 2009.Applications of proton-induced Xray emission technique in materials and environmental science. Ovidius Univ.J. Ann. Chem. 20(1):30- 35.

Eva, D.B., Anneleen, F., Benjamin, L., Rudy, S., Cheryl, J., Mehmet, Ö. \& Aurélien, V. 2016. Comparative study of the Pleistocene Cakmak quarry (Denizli Basin, Turkey) and modern Mammoth Hot Springs deposits. J.Quaternary International. 6: $74-83$.

Falk, E.S., Guo, W., Paukert, A.N., Matter, J.M., Mervine, E.M. \& Kelemen, P.B. 2016. Controls on the stable isotope compositions of travertine from hyperalkaline springs in Oman: Insights from clumped isotope measurements. J.Geochimica et Cosmochimica Acta. 192: 1-28.

Fernández, M., Margalef ,O., Sayol, F., Asensio, D. \& Preece, C. 2019. Sea spray influences water chemical composition of Mediterranean semi-natural springs.J. CATENA. 173: 414-423.

Fujiwara, S. \& Takashi, M. 2007. Analysis of Chemical States of Heavy Metals in Environmental Samples Using XFAS.JFE TECHNICAL REPORT No.9.

Gautam, P. \& Irfan A. 2011. Heavy Metals Contamination Assesment of Kanhargon Dam Water Near Chhindwara City. J.Acta Chimica and Pharmaceutica Indica. 2: 7-9.

Gebrekidan, M. \& Samuel Z. 2011. Concentration of Heavy Metals in Drinking Water from Urban Areas of the Tigray Region. J.Northern Ethiopia. 3:9-18.

Gill G., Geesey, Tamar B. \& Sue K. 2016. Microbes in mercury-enriched geothermal springs in western North America. J.Science of The Total Environment. 569: 321-331. 
Kawashima, Y., 2003. Basic investigation on the chemical forms of heavy metals in sewer. J. of Jpn. Sewage Works Association. 40(486): 127-139.

Mauricio, O.M., Prosun, B., Ondra, S., Oswaldo R., Jorge Q.A., Jochen, B. \& Jyoti, P. M. 2015. Arsenic and other trace elements in thermal springs and in cold waters from drinking water wells on the Bolivian Altiplano. J. of South American Earth Sciences. 60: 10-20.

Muhammad, T., Abdullah, A., Amani, A. \& Nidal, H. 2018. Membrane separation as a pre-treatment process for oily saline water, Desalination. 447: 182-202.

Nagoshi, M. 2005. Chemical States of Trace Heavy Metals in Sewage Sludge by XAFS Spectroscopy. J.Pyysica Scripta. 115 : 946-948.

Nakahara, K. 2003. The change of chemical states of heavy metals in sewage sludge. The 40th Annual Conf. of Jpn Sewage Works assosication. 4: 907-909.

Nathan, C. Twaddle, Michelle, V., Frederick, A. \& Daniel, R. 2019. Metabolism and disposition of arsenic species from controlled dosing with dimethylarsinic acid (DMAV) in adult female CD-1 mice. V. Toxicokinetic studies following oral and intravenous administration. Food and Chemical Toxicology. 130: 22-31.

Ogoyi, O., Mwita, C.J. , Nguu, E.K. \& Shiundu, P.M. 2011. Determination of Heavy Metal Content in Water. Sediment and Microalgae from Lake Victoria, East Africa. J.The Open Environmental Engineering Journal. 4:1-9.

Pantelica, V., Cercasov, E., Steinnes, P., Bode, B. \& Wolter, b. 2008. Investigation by INAA, XRF, ICPM Sn and PIXE of Air Pollution Levels at Galati (Siderurgical Site). 4th Nat. Conf. of Applied Physics (NCAP4). Galati, Romania.

Popescu, I.V., Stihi, C., Cimpoca, Gh.V., Dima, G., Vlaicu, Gh., A., Gheboianu, I., Bancuta, V. \& Ghisa, G. 2009. Environmental Samples Analysis by Atomic Absorption Spectrometry (AAS) and Inductively Coupled Plasma-Optical Emission Spectroscopy (ICP-AES), J.Rom. Journ. Phys. 54: 7-8.

Saito, N. 2003. The basic property of reduction of arsenic and selenium by anaerobic bacteria. The 40th annual conference of Japan sewage works assn. Tokyo,Japan.

Sonia, L., José, L. E., María, V., Esteller, Miguel, A. G., Guillermo, P., Morales. 2019. Prioritization to protect springs for public urban water supplies, based on multi-criteria evaluation and GIS. J.Applied Geography. 107: 26-37.

Stihi, A., Bancuta, I.V., Popescu, M., Virgolici, V., Cimpoca, M. \& Gugiu, G.V. 2010. Air pollution studies using PIXE and ICP Methods. J. of Physics. 41: 565 -571.

World Health Organization, 2017. Conference in Geneva. 